\title{
A STUDY ON THE USE OF SOME NATURAL EXTRACTS AS ANTI- FUNGI TO PROLONG THE CONSERVATION OF WHEAT AND ITS PRODUCTS. \\ Emara, M.F.'; A. M. M. El-Karamany ${ }^{1}$; Nemat I. Bassuony ${ }^{1}$; M. A. Atwa ${ }^{1}$; Manal A. Atwa ${ }^{1}$ and S.A. Soliman ${ }^{2}$. 1- Regional Center for Food \& Feed. Agric. Res. Center, Giza, Egypt. 2- Food Technology Research Institute, Agric. Res. Center, Giza Egypt
}

\begin{abstract}
Different extracts of carrot seeds, leaves, and roots were evaluated for their effectiveness inhibition on some groups of microorganism fungal growth and reducing the production of aflatoxins. Ethanol, Chloroform, and water showed effects against some groups of microorganisms which contaminated wheat products. Water and chloroform extracts of yellow carrot leaves showed the most effect against feacal group. Water, ethanol and chloroform extracts from carrot seeds, leaves, and root reduced the fungal growth rate of Penicillum funiculosum, Fusarium compactum, fusarium chlamydosporum, Fusarium monilliforme, fusarium roseum, Aspergillas niger, Aspergillus fumagatus, Fusarium solani. No aflatoxin was produced by fungi in wheat samples treated by extracts of carrot seeds, herbs, and roots.
\end{abstract}

Keywords: Carrots,fungal growth, preservation and aflatoxins

\section{INTRODUCTION}

Wheat is the world's most important food grain. In general, wheat is mainly consumed in bakery products manufactured from endosperm flour, which forms $83 \%$ of the kernel, and has unique technological properties for creating superior, consumer appealing product quality in terms of flavor and texture. (Jacobs et al., 1998, Liu et al., 2000, Pereira et al., 2002). Dietary fiber and other functional food products with specific physiological functions of health, which are concentrated in the outer layers of the grains (bran), and forms $14 \%$ of kernel. However, additions of cereal bran, especially in such amounts that health benefits can be expected, cause several problems in the flavor and texture. In addition, bran fraction is rich in spoilage organisms such as rope forming bacteria Bacillus subtilis which increases the challenges to retain microbiological safety of wheat breads supplemented with bran.

It is estimated that between 5 and $10 \%$ of the world's food production is lost due to fungal deterioration.

In Western Europe, mould spoilage of bread alone is estimated to cause than £200 million (Legan, 1993).

Aflatoxins, a group of naturally occurring toxins produced by the molds Aspergillus flavus and Aspergillus parasiticus, sometimes contaminate a variety of foods and feeds. Several investigators have demonstrated that Aflatoxin are acutely toxic, carcinogenic, teratogenic and mutagenic. Aflatoxin B1 (AF B1) is the most toxic of the group and appears naturally in the largest quantities (Applebaum and Marth, 1982).Toxins that could be produced by some members of the genus fusarium such as F. verticillioides, are toxic 
substances to human and animals (Chen and Zhang, 1987, Gelderblom et al., 1998).

It is important to investigate scientifically those plants which have been used in traditional medicines as potential sources of novel antimicrobial compounds (Mitscher et al., 1987). Also, the resurgence of interest in natural therapies and increasing consumer demand for effective, safe, natural products means that quantitative data on plant oils and extracts are required. Extracts from many of plant species have been screened for the presence of antimicrobial substances that can be used in controlling plant diseases. Medicinal and some indigenous plants are important sources of biologically active compounds against phytophathogenic fungi and bacteria as well as plant diseases (Wiader and Lamer, 1996, EL-Kazzaz et al., 2003).

Some investigators tried to decrease the production of mycotoxins by introducing plant extracts or essential oils to the fungal growing media or the food commodity. Growth of A. flavus and aflatoxin production was also inhibited by citrus peel extracts (Abdalla et al., 2001). Chamomile, cinnamon and pepper have the potential to decrease the growth of fungi as well as formation and accumulation of mycotoxins. (Abdelhamid et al., 1995). Chloroform extract of carrot root tissue inhibited Aflatoxin production by $A$. parasiticus but did not affect the mycelia weight of culture. The inhibitory activity was $\mathrm{PH}$ dependent and inhibition was lost when the initial $\mathrm{pH}$ was 6.0 or higher. (Batt et al., 1980). Purified ethanolic extracts of peeled and shredded carrots showed an antimicrobial effect against a range of foodborne, micro-organisms. (Babic et al., 1994).

Cultivars of carrot differ in their essential oil contents and leaves have higher amount of essential oils than the roots. (Senalik and Simoin, 1987; Kainulainen et al., 1998, 2002 ;Habegger and Schnitzler, 2000). The principal compounds in the leaves were $\beta$-myrcene, $\alpha$-asarone, methyl isoeugenol, $\beta$ caryophyllene, (E)- $\beta$-farnesene, limonene and sabinene. While, in roots, the main compounds were $\alpha$-pinene, sabinene, $\beta$ - pinene, $\beta$-myrcene, limonene, total monoterpenes and $(E)$ - $\beta$-farnesene.

This study was done in the laboratory to evaluate the efficiency of two cultivated (red and yellow) carrot seed, leaves, and root extracts against some plant pathogenic fungi. The possibility of reducing the production of aflatoxin and fumonisin by the most effective extracts was also studied.

\section{MATERIALS AND METHODS}

The present work was carried out in the Regional Center for Food and Feed and Food Technology Research Institute, Agriculture Research Center, Giza, Egypt.

- Wheat variety Giza 168 was obtained from Wheat Research Department, Field Crops Research Institute, ARC. Giza. Egypt.

- Two varieties of fresh carrot (red and yellow) and yellow carrot seeds were purchased from local market. 


\section{Preparation of carrot leaves, root and seeds powders:}

Carrot leaves and root powders were washed and chopped fairly thinly. The materials were dried in cabinet dryer at $60-65^{\circ} \mathrm{C}$ temperature $80 \mathrm{~m} / \mathrm{h}$ air flow rate for $24 \mathrm{~h}$. After drying the pieces of leaves and root and seeds were ground separately using a Maxy Hermetic Mill Grinder, patent N: 53985 B, Italy.

\section{2- Preparation of carrot leaves, roots and seeds extracts:}

Water, ethyl alcohol $(96 \% \mathrm{~V} / \mathrm{V})$ and chloroform was used to extract the antimicrobial compounds in red or yellow carrot leaves, roots and seeds. The extracts were prepared according to the method given by Ashour (1989) as follows: $50 \mathrm{gm}$ plants or seeds powder were mixed with $500 \mathrm{ml}$ solvent, water only was used hot $\left(90^{\circ} \mathrm{C}\right)$. Mixtures were kept in dark at room temperature for four days intermittent stirring (3-4 times for 5 min. daily) and filtered through whatman No. 40 filter paper. Extracts were evaporated to dryness (by rotary evaporator ) to determine the weight of the extracted material before transferred to $3 \%$ extract ( $3 \mathrm{gm}$ of extracted material) in $100 \mathrm{ml}$ measuring flask using the same solvent. The extracts were kept in refrigerator at $4-7^{\circ} \mathrm{C}$.

\section{3- Preparation of wheat samples :}

1 -Wheat was sampled into sixteen samples $(500 \mathrm{gm})$.

2-Wheat samples conditioning: in this process water is added to temper wheat samples to $15 \%$ moisture, and allowed to stand for up to 24 hours in closed cans to secure maximum toughening of the bran with optimum mellowing of the starchy endosperm. The quantity of added water was calculated from the follow equation:

Added water $\%=$ Wheat sample weight $X(15-\%$ wheat sample moisture/100-14)

3- Wheat samples milling: wheat samples were milled in a standard Brabender Duisburg laboratory mill, Type 279002, Germany, Break and reduction flours were collected and sieved into (flour, fine bran, coarse bran, brown shorts and white bran).

4-Chemical analysis:

Wheat and its mill product samples were analyzed for moisture, ether extract, ash, protein and crude fiber according to the methods described in the A.O.A.C. (1995). Carbohydrates were determined by difference.

\section{5-Bacteriological experiments:}

The obtained extracts were evaluated for their efficiency in reducing the microbial load and growth of molds under study in wheat and its mill products (whole grain, flour, fine bran, coarse bran, brown shorts and white shorts). Wheat was divided into sixteen samples treated with different extracts as the follows:

1.Three of wheat samples were treated with a known volume $5 \mathrm{ml}$ (each $1 \mathrm{ml}$ give the required concentration $0.03 / 100 \mathrm{gm}$ wheat) of ethanol extracts of yellow carrot (leaves, roots or seeds) .

2.Two of wheat samples were treated with $5 \mathrm{ml}$ of ethanol extracts of red carrot leaves or roots.

3.Three of wheat samples were treated with $5 \mathrm{ml}$ of chloroform extracts of yellow carrot (leaves, roots or seeds).

4. Two of wheat samples were treated with $5 \mathrm{ml}$ of chloroform extracts of red carrot (leaves or roots). 
5.Two of wheat samples were treated with $5 \mathrm{ml}$ of water extracts of yellow carrot (leaves or roots).

6. Two of wheat samples were treated with $5 \mathrm{ml}$ of water extracts of red carrot (leaves or roots).

7.One samples was treated with $0.03 \%$ sodium propionate (as a positive control)

8. The last sample was treated with water only (as a negative control).

All extracts were added to water, which was used during wheat samples conditioning, then, the samples were milled. Wheat and its products samples were analyzed for its moisture contents poured into bottles at room temperature for bacteriological analysis after months and 6 months.

Table (1): Average of daily temperature and specific humidity during the experiment months

\begin{tabular}{|l|c|c|c|c|c|c|c|}
\hline \hline Marameters Months & April & May & June & July & August & September & October \\
\hline Average of daily temperature C은 & 25.3 & 26.7 & 28.5 & 29.4 & 30.4 & 29.0 & 24.1 \\
\hline Average of specific humidity & 43.3 & 48.0 & 54.0 & 63.0 & 61.0 & 60.0 & 65.0 \\
\hline
\end{tabular}

\section{6- Bacteriological evaluation:}

Appropriate dilutions prepared from each sample were used for inoculating different nutrient and selective media. The microbial determinations were applied as follows:

\section{A) Total aerobic viable counts:}

Aerobic bacterial counts were estimated on glucose yeast extract nutrient agar medium as the method reported by (APHA, 1990) using pouring plate technique. Suitable plates were counted after incubation at $37 \mathrm{C}^{\circ}$ for 48 hours.

\section{B) Coliform and faecal coliform counts}

Coliform and faecal coliform counts were estimated on MacConkey ager (APHA, 1990) using pouring plate technique. Suitable plates were counted after 24 hours at $37 C^{\circ}$ and $44.5 C^{\circ}$ for total coliform and faecal coliform counts, respectively.

\section{C) Determination of total counts of fungi}

Total counts of fungi were determined on potato dextrose agar days and the counts of fungi (cfu /g) were determined as described in American Public Health, Association (1981) and Oxoid Manual (2000). Isolation and identification of fungi.

Developed colonies on PDA medium were transferred to PDA slants and purified using the single spore technique (Hansen, 1926) and / or hyphal tip technique (Riker and Riker, 1936). Purified isolates were identified according to their morphological and microscopical characters and confirmed by Dept., Plant Pathology institute ARC, Egypt.

\section{D) Mycotoxins analysis:}

All standards of mycotoxins were purchased from Sigma company, U.S.A. All chemicals and solvents used were of ACS grade. Thin layer chromatography (TLC) was performed using $20 \times 20 \mathrm{~cm}$ TLC aluminum plates recoated with $0.25 \mathrm{~mm}$ silica gel 60 (Merck). Aflatoxins were extracted 
by B.F. method as described in AOAC (1998). Extracts were dissolved in 200 $\mu \mathrm{L}$ chloroform and vortexed, then $20 \mu \mathrm{L}$ aliquot and $10 \mu \mathrm{L}$ of the standards were spotted on TLC plates and developed in dark room with ethyl ether: methanol: water (96: 3:1). After drying, the spots were examined with U.V at a wave length of $365 \mathrm{~nm}$ (AOAC 1998).

\section{RESULTS AND DISCUSSION}

\section{*Chemical composition of raw materials:}

The chemical composition of whole grain, flour, fine bran, coarse bran, brown shorts and white shorts was studied and the obtained results are shown in Table (1). It could be noticed that moisture, protein, fat, crude fiber and ash contents of fine bran, coarse bran, brown shorts and white shorts were higher than wheat flour. White shorts has the highest percent of moisture and protein, while wheat flour has highest percent of total carbohydrates. Protein content increased in the out layers of wheat grain. Coarse bran has the highest percent of crude fiber (11.4\%), follows by fine bran $(8.5 \%)$ and brown shorts (5.5\%). These results are in agreement with those reported by( Faheid and Hegazy, 1991).

The moisture contents of the wheat products after mill processing are presented in Table (3).

From the results in Table (3) it be noticed that coarser bran samples had the highest amount of moisture contents, while wheat flour samples had the lowest amount of moisture contents.

Total aerobic plate counts (T.A.C) total Coliforms counts (T.C.C), Fecal coliforms counts (F.C.C), Molds counts, total aflatoxins levels and isolated fungi of some wheat products were determined as seen in Table (4). The highest number of isolated fungi was obtained from most wheat products which were averaged between $2 \times 10^{-4}$ to $7 \times 10^{-3}(\mathrm{CFU} / \mathrm{g})$.

Table (2): Chemical composition of whole grain, flour, fine bran, coarse bran, brown shorts and white shorts.

\begin{tabular}{|l|c|c|c|c|c|c|}
\hline \multirow{2}{*}{ Samples } & \multirow{2}{*}{$\begin{array}{c}\text { Moisture } \\
\%\end{array}$} & $\begin{array}{c}\text { Protein } \\
\%\end{array}$ & $\begin{array}{c}\text { Fat } \\
\%\end{array}$ & $\begin{array}{c}\text { Crude } \\
\text { fiber\% }\end{array}$ & $\begin{array}{c}\text { Ash } \\
\%\end{array}$ & $\begin{array}{c}\text { Total } \\
\text { carbohydrates\% }\end{array}$ \\
\hline Whole grain of wheat & 10.5 & 15.5 & 1.3 & 2.4 & 1.8 & 79.08 \\
\hline Wheat flour & 12.5 & 10.8 & 0.35 & 0.43 & 0.55 & 87.87 \\
\hline Fine bran & 13.0 & 15.1 & 3.2 & 8.5 & 3.9 & 69.3 \\
\hline Coarse bran & 13.0 & 13.7 & 4.0 & 11.4 & 4.7 & 66.2 \\
\hline Brown shorts & 14.0 & 14.8 & 4.5 & 5.5 & 3.8 & 71.4 \\
\hline White shorts & 14.5 & 17.5 & 3.7 & 2.1 & 2.7 & 74.0 \\
\hline
\end{tabular}

The moisture contents of the wheat products after mill processing are presented in Table (3).

From the results in Table (3) it be noticed that coarser bran samples had the highest amount of moisture contents, while wheat flour samples had the lowest amount of moisture contents.

Total aerobic plate counts (T.A.C) total Coliforms counts (T.C.C), Fecal coliforms counts (F.C.C), Molds counts, total aflatoxins levels and isolated 
fungi of some wheat products were determined as seen in Table (4). The highest number of isolated fungi was obtained from most wheat products which were averaged between $2 \times 10^{-4}$ to $7 \times 10^{-3}(\mathrm{CFU} / \mathrm{g})$.

Table (3): Moisture contents of wheat products after mill processing.

\begin{tabular}{|c|c|c|c|c|c|c|c|}
\hline \multirow{2}{*}{\multicolumn{2}{|c|}{ Treatments }} & \multirow{3}{*}{$\begin{array}{l}\text { Type of extract } \\
\text { Water extract }\end{array}$} & \multicolumn{5}{|c|}{ Moisture content of Wheat products $\%$} \\
\hline & & & \multirow{2}{*}{$\begin{array}{c}\begin{array}{c}\text { Red } \\
\text { shorts }\end{array} \\
13.8 \\
\end{array}$} & \multirow{2}{*}{$\begin{array}{c}\begin{array}{c}\text { White } \\
\text { shorts }\end{array} \\
13.3 \\
\end{array}$} & \multirow{2}{*}{$\begin{array}{c}\text { Flour } \\
12.8 \\
\end{array}$} & \multirow{2}{*}{$\begin{array}{c}\begin{array}{c}\text { Fin } \\
\text { bran }\end{array} \\
14.8\end{array}$} & \multirow{2}{*}{\begin{tabular}{|c|}
$\begin{array}{c}\text { Courser } \\
\text { bran }\end{array}$ \\
15.1 \\
\end{tabular}} \\
\hline \multirow{6}{*}{ Red carrot } & \multirow{3}{*}{ Herb } & & & & & & \\
\hline & & Ethanol extract & 13.8 & 13.4 & 12.8 & 14.7 & 15.0 \\
\hline & & Chloroform extract & 14.0 & 13.6 & 13.1 & 14.8 & 15.0 \\
\hline & \multirow{3}{*}{ Root } & \begin{tabular}{|l|l} 
Water extract \\
\end{tabular} & 13.8 & 13.5 & 12.9 & 14.6 & 14.8 \\
\hline & & Ethanol extract & 13.5 & 13.1 & 12.5 & 14.3 & 14.4 \\
\hline & & Chloroform extract & 14.3 & 13.9 & 13.1 & 15.0 & 15.3 \\
\hline \multirow{8}{*}{ Yellow carrot } & \multirow{3}{*}{ Herb } & Water extract & 13.9 & 13.1 & 12.6 & 14.7 & 15.1 \\
\hline & & Ethanol extract & 13.9 & 13.6 & 13.3 & 14.7 & 15.1 \\
\hline & & Chloroform extract & 14.4 & 13.7 & 13,4 & 15.3 & 15.3 \\
\hline & \multirow{5}{*}{ Root } & Water extract & 14.4 & 13.7 & 13.2 & 15.0 & 15.0 \\
\hline & & Ethanol extract & 14.3 & 13.7 & 13.2 & 15.2 & 15.8 \\
\hline & & Chloroform extract & 14.8 & 13.6 & 13.0 & 15.7 & 18.1 \\
\hline & & Ethanol extract & 14.4 & 14.0 & 13.8 & 16.3 & 17.2 \\
\hline & & Chloroform extract & 14.4 & 13.5 & 13.0 & 15.5 & 16.5 \\
\hline \multicolumn{3}{|c|}{ Sodium propionate } & 14.9 & 14.5 & 13.6 & 15.8 & 16.5 \\
\hline \multicolumn{3}{|l|}{ Water } & 13.6 & 13.3 & 13.3 & 14.7 & 15.3 \\
\hline
\end{tabular}

Table (4): Initial total Aerobic plate counts, total coliform, fecal coliform, molds counts, total aflatoxins and Isolated fungi of examined, wheat and wheat product.

\begin{tabular}{|c|c|c|c|c|c|c|}
\hline Sample & $\begin{array}{c}\text { TAC } \\
\left(\mathrm{CFU} \mathrm{g}^{-1}\right)\end{array}$ & $\begin{array}{c}\text { TCC } \\
\left(\mathrm{CFU} \mathrm{g}^{-1}\right)\end{array}$ & $\begin{array}{l}\text { FCC } \\
(\mathrm{CFU} \\
\left.\mathbf{g}^{-1}\right)\end{array}$ & $\begin{array}{l}\text { Mold } \\
\text { (CFU } \\
\left.g^{-1}\right)\end{array}$ & Isolated fungi & $\begin{array}{l}\text { Total } \\
\text { Aflatoxin } \\
\text { content } \\
(\mu \mathrm{g} / \mathrm{Kg}) \\
\end{array}$ \\
\hline $\begin{array}{l}\text { Whole } \\
\text { grain of } \\
\text { wheat }\end{array}$ & $14 \times 10^{-1}$ & $13 \times 10^{-1}$ & N.D & $7 \times 10^{-3}$ & $\begin{array}{|lc|}\text { Penicillum } & \text { funiculosum } \\
\text { fusarium } & \text { compactumo } \\
\text { fusarium chlamydosporum }\end{array}$ & 0.0 \\
\hline $\begin{array}{l}\text { Wheat } \\
\text { flour }\end{array}$ & $6 \times 10^{-3}$ & $13 \times 10^{-3}$ & N.D & $8 \times 10^{-4}$ & \begin{tabular}{|l|} 
Aspergillus Niger \\
Aspergillus Aculeatus \\
Aspergillus flavus \\
Penicillium digitatum
\end{tabular} & 0.0 \\
\hline $\begin{array}{l}\text { Brown } \\
\text { shorts }\end{array}$ & $7 \times 10^{-2}$ & $15 \times 10^{-1}$ & N.D & $2 \times 10^{-4}$ & $\begin{array}{l}\text { Fusarium pallidoroseum } \\
\text { Penicillium digitatusm }\end{array}$ & 0.0 \\
\hline $\begin{array}{l}\text { White } \\
\text { shorts }\end{array}$ & $5 \times 10^{-2}$ & $25 \times 10^{-3}$ & N.D & $2 \times 10^{-4}$ & $\begin{array}{l}\text { Fusarium pallidoroseum } \\
\text { Penicillium digitatusm }\end{array}$ & 0.0 \\
\hline Fine bran & $50 \times 10^{-2}$ & $11 \times 10^{-2}$ & N.D & $3 \times 10^{-3}$ & $\begin{array}{l}\text { Aspergillus niger } \\
\text { Fusarium rosum } \\
\text { Fusarium solani }\end{array}$ & 0.0 \\
\hline $\begin{array}{l}\text { Coarse } \\
\text { bran }\end{array}$ & $10 \times 10^{-1}$ & $13 \times 10^{-2}$ & $35 \times 10^{-2}$ & $4 \times 10^{-3}$ & $\begin{array}{l}\text { Fusarium monilliforme } \\
\text { Fusarium rosum } \\
\text { Aspergillus fumagatus } \\
\text { Ochraceus sp. }\end{array}$ & 0.0 \\
\hline
\end{tabular}

$\left({ }^{*} \mathrm{CFU}\right)=$ Cell forming unit.

Isolated fungi were identified as Penicillum funiculosum, Fusarium compactum, Fusarium chlomydosporum, Fusarium monilliforme, Fusarium rosum, Aspergillus fumagatus, Ochraceus sp., Aspergillus niger, Aspergillus 
flavus, Penicillium digitatum, Fusarium solani, and Fusarium pallidoroseum. All investigated samples were free of aflatoxins as seem in the same Table(4).

The microbial load of the wheat products samples indicated that the T.A.C were ranged from $6 \times 10^{-3}$ to $10 \times 10^{-1} \mathrm{CFU} / \mathrm{g}$, while the F.C.C were 0.0 $\mathrm{CFU} / \mathrm{g}$ in all samples except it was $35 \times 10^{-2} \mathrm{CFU} / \mathrm{g}$ in coarser bran sample, and T.C.C levels were ranged from $13 \times 10^{-3}$ to $15 \times 10^{-1} \mathrm{CFU} / \mathrm{g}$ in the same samples.

The initial total Aerobic plate $60 \mathrm{mts}$, total coliform, fecal coliform, molds, total aflatoxins and isolated fungi of examined carrots products were shown in Table (5) cont.

Table (5): Initial total Aerobic plate counts, total coliform, fecal coliform, mold, total aflatoxins and isolated fungi of examined carrots product.

\begin{tabular}{|c|c|c|c|c|c|c|}
\hline Sample & $\begin{array}{c}\text { ATC } \\
(\text { CFU g-1) }\end{array}$ & $\begin{array}{c}\text { TCC } \\
\left(\mathrm{CFU} \mathrm{g} \mathrm{g}^{-1}\right)\end{array}$ & $\begin{array}{c}\text { FCC } \\
\left(\mathrm{CFU} \mathrm{g} \text { g }^{-1}\right)\end{array}$ & $\begin{array}{c}\text { Mold } \\
\left(\text { CFU g }{ }^{-\mathbf{1}}\right)\end{array}$ & Isolated fungi & $\begin{array}{c}\text { Total } \\
\text { Aflatoxin } \\
\text { content } \\
(\mu \mathrm{g} / \mathrm{Kg})\end{array}$ \\
\hline $\begin{array}{l}\text { Yellow } \\
\text { carrot roots }\end{array}$ & $83 \times 10^{-4}$ & $15 \times 10^{-4}$ & N.D & $2 \times 10^{-3}$ & $\begin{array}{l}\text { Alternaria Sp. } \\
\text { Alternaria teruis sp }\end{array}$ & 0.0 \\
\hline $\begin{array}{ll}\text { Red } & \text { carrot } \\
\text { roots } & \end{array}$ & $83 \times 10^{-4}$ & $15 \times 10^{-4}$ & N.D & $2 \times 10-3$ & $\begin{array}{l}\text { Alternaria Sp. Alternaria } \\
\text { tenuis Sp. }\end{array}$ & 0.0 \\
\hline $\begin{array}{l}\text { Yellow } \\
\text { carrot seeds }\end{array}$ & $6 \times 10^{-2}$ & $3 \times 10^{-2}$ & N.D & $1 \times 10^{-2}$ & $\begin{array}{l}\text { Aspergillus sydowii } \\
\text { Alternaria Sp. } \\
\text { Alternaria tenuis Sp. }\end{array}$ & 0.0 \\
\hline $\begin{array}{l}\text { Yellow } \\
\text { carrot leaves }\end{array}$ & $175 \times 10^{-4}$ & $190 \times 10^{-4}$ & N.D & $2 \times 10^{-2}$ & $\begin{array}{l}\text { Chlamydos porum } \\
\text { Alternaria Sp. } \\
\text { Aspergillus sydowii }\end{array}$ & 0.0 \\
\hline $\begin{array}{l}\text { Red carrot } \\
\text { leaves }\end{array}$ & $166 \times 10^{-4}$ & $174 \times 10^{-4}$ & N.D & $5 \times 10^{-2}$ & $\begin{array}{l}\text { Chlamydos porum } \\
\text { Alternaria Sp. } \\
\text { Aspergillus sydowii }\end{array}$ & 0.0 \\
\hline
\end{tabular}

F.C.C = total aerobic counts.

T.C.C = total coliforms counts.

Table (6,7 and 8) showed that the effect of water, ethanol and chloroform extracted of red and yellow carrot (leaves, roots or seeds) on the microbial load, fungal growth and its aflatoxin production for some wheat products after 1 month of storage.

The obtained data indicated that the addition of water extracted of red carrot roots to wheat products samples was more effective for reducing the molds counts, which recorded numbers of $1 \times 10^{-1} \mathrm{CFU} / \mathrm{g}$. Molds counts were $0.0 \mathrm{CFU} / \mathrm{g}$ for fine and course bran by using water extracted carrot leaves. The counts of molds in wheat products were ranged from $1 \times 10^{-1}$ to $2 \times 10^{3}$, $1 \times 102$ to $9 \times 10^{3}$, and $1 \times 10^{2}$ to $1 \times 10^{3}$ for the treatments with ethanol extracted of red carrot root, yellow carrot root, and yellow carrot seeds, respectively. The given data showed that the best treatment was achieved by using chloroform extracted yellow carrot seeds with fine bran which recorded $0.0 \mathrm{CFU} / \mathrm{g}$. 
The obtained data indicated that the addition of ethanol extracted of red carrot herbs was more effective for reducing the total aerobic bacteria which recorded the number of $16 \times 10^{2}$ to $10 \times 10^{1} \mathrm{CFU} / \mathrm{g}$, while it was $4 \times 10^{2}$ to $55 \times 10^{3} \mathrm{CFU} / \mathrm{g}$, with the treatment of yellow and red carrot root. Suing yellow carrot herbs did not showed any effective for the numbers of total aerobic bacteria. Treatments with water as sodium propionate had no effect too.

Total coliform counts were determined in all wheat products samples treated by the extracted carrot products samples treated by the extracted carrot products. Data showed that the addition of all extracted yellow and red carrot herbs was more effective for reducing numbers of total coliform, which recorded $0.0 \mathrm{CFU} / \mathrm{g}$ in the most type of samples. Some results were achieved by using of all extracted of carrot roots. Extracted carrot seeds had no effective for the numbers of total coliforms, while treatment with sodium propionate showed less effective for total coliform counts which recorded rang of $7 \times 10^{1}$ to $20 \times 10^{1} \mathrm{FCU} / \mathrm{g}$. It was ranged from $17 \times 10^{2}$ to $25 \times 10^{2}$, in case of treatment with water only.

Table (6): Effect of water extracted of red and yellow carrot (leaves and roots) on the microbial load and fungal growth on some wheat products after 1 month of storage.

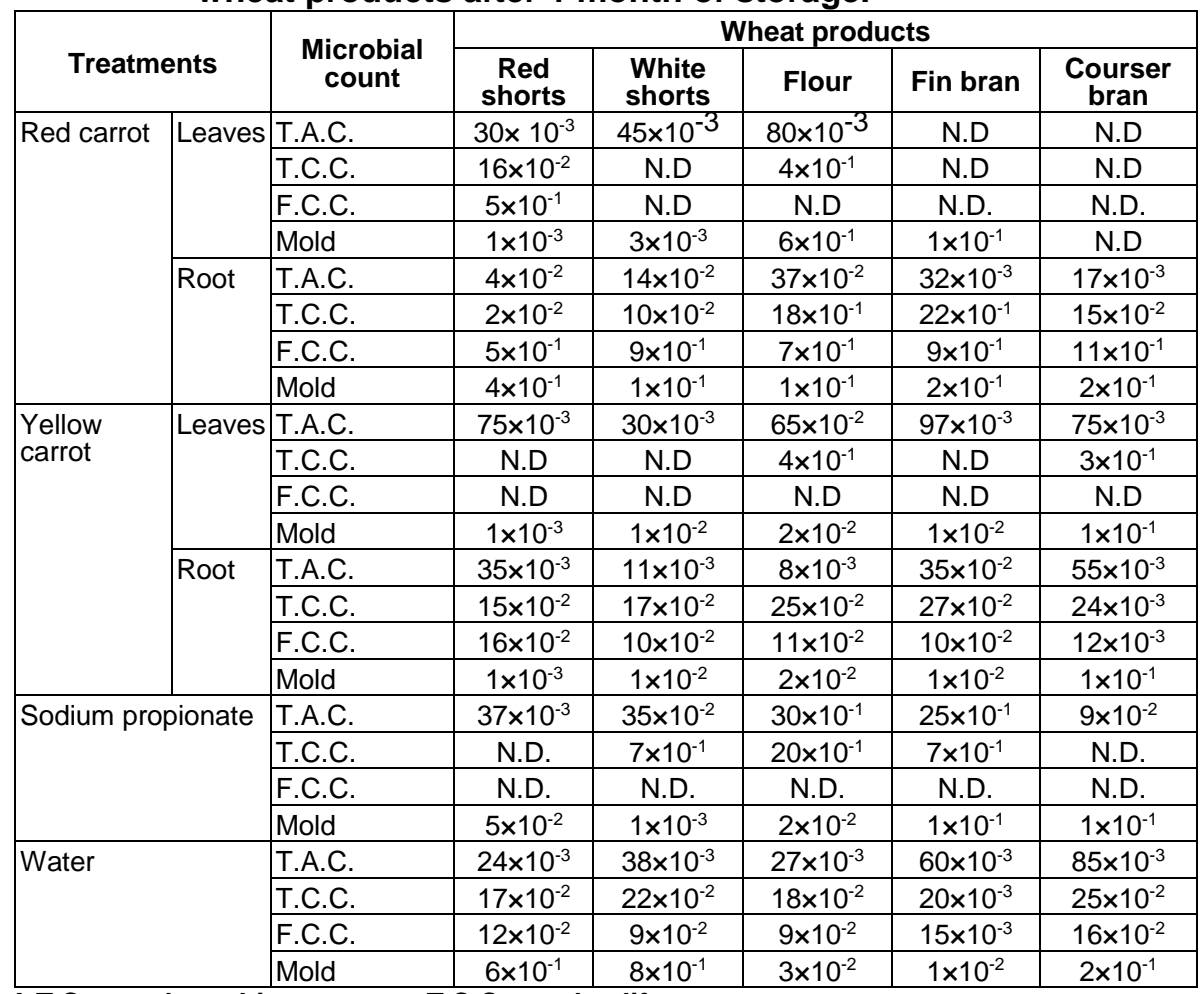

A.T.C $=$ total aerobic counts. T.C.C $=$ total coliforms counts.

F.C.C $=$ fecal coliforms counts. 
Table (7): Effect of Ethanol extracted of red and yellow carrot (leaves, roots and seeds) on the microbial and fungal growth on some wheat products after 1 month of storage.

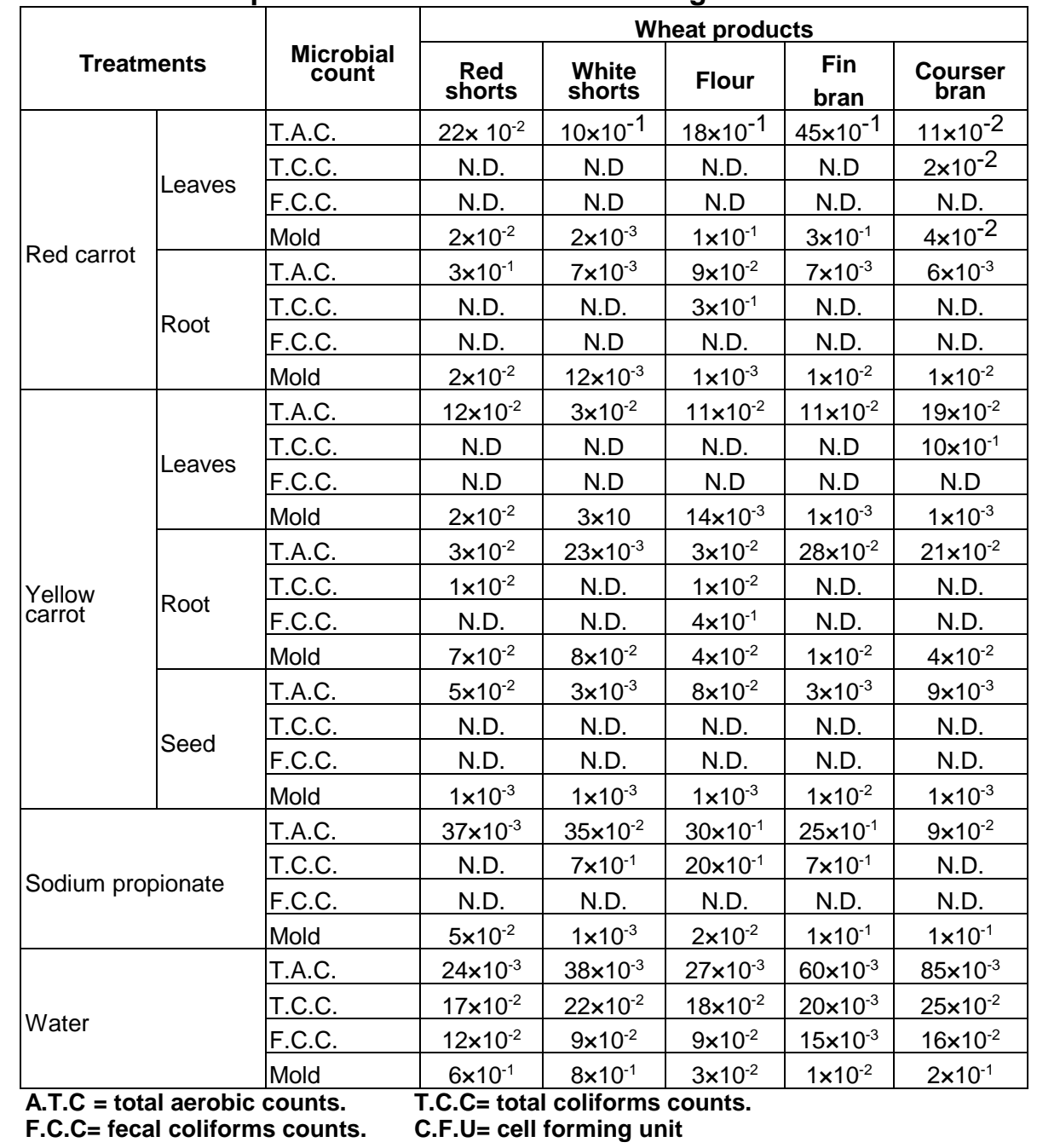

On the other hand, fecal coliforms counts were effected by addition of ethanol and chloroforms extracted carrots (root and herb), compared with extracted water which caused more contamination $\left(5 \times 10^{1}\right.$ to $\left.12 \times 10^{3} \mathrm{CFU} / \mathrm{g}\right)$.

The addition of water to wheat products showed more counts of fecal coliforms which recorded $9 \times 10^{-2}$ to $15 \times 10^{-3} \mathrm{CFU} / \mathrm{g}$.

The effect of water, ethanol and chloroform extracted of red and yellow carrot (herbs and roots) on the microbial load of wheat products samples compared with that treated by water or sodium propionate as seen in the same table. 
M.F. Emara et al.

Regarding the addition of carrots extracts, data indicated that the effects on the numbers of total aerobic bacteria was achieved as a result of inhibition effect of antimicrobial compounds of carrot. The obtained data are similar with that mentioned by (Babic et al 1994), who reported that the antimicrobial compounds of carrot play a major role in the resistance to microbial load. An antimicrobial activity was detected in purified carrot extract. Phenolic compounds, falacarindiol, free saturated fatly acid (dedecanoic acid) and methyl esters of satured fatty acids (of dedecanoic and pentadecanoic acids).

Table (8): Effect of chloroform extracted of red and yellow carrot (leaves, roots and seeds) on the microbial load and fungal growth on some wheat products after 1 month of storage.

\begin{tabular}{|c|c|c|c|c|c|c|c|}
\hline \multirow{2}{*}{\multicolumn{2}{|c|}{ Treatments }} & \multirow{3}{*}{\begin{tabular}{|l}
$\begin{array}{c}\text { Microbial } \\
\text { count }\end{array}$ \\
T.A.C. \\
\end{tabular}} & \multicolumn{5}{|c|}{ Wheat products } \\
\hline & & & \multirow{2}{*}{$\begin{array}{c}\begin{array}{c}\text { Red } \\
\text { shorts }\end{array} \\
10 \times 10^{-2} \\
\end{array}$} & \multirow{2}{*}{$\begin{array}{c}\begin{array}{c}\text { White } \\
\text { shorts }\end{array} \\
10 \times 10^{-1}\end{array}$} & \multirow{2}{*}{$\begin{array}{c}\text { Flour } \\
75 \times 10^{-1}\end{array}$} & \multirow{2}{*}{$\begin{array}{l}\text { Fin bran } \\
30 \times 10^{-1}\end{array}$} & \multirow{2}{*}{$\begin{array}{c}\begin{array}{c}\text { Courser } \\
\text { bran }\end{array} \\
16 \times 10^{-1} \\
\end{array}$} \\
\hline \multirow{8}{*}{ Red carrot } & \multirow{4}{*}{ Leaves } & & & & & & \\
\hline & & T.C.C. & $2 \times 10^{-1}$ & $2 \times 10^{-1}$ & $19 \times 10^{-1}$ & $7 \times 10^{-1}$ & N.D. \\
\hline & & F.C.C. & N.D. & N.D. & $9 \times 10^{-1}$ & N.D. & N.D. \\
\hline & & Mold & $1 \times 10^{-2}$ & $4 \times 10^{-1}$ & $1 \times 10^{-2}$ & $1 \times 10^{-1}$ & $1 \times 10^{-3}$ \\
\hline & \multirow{4}{*}{ Root } & T.A.C. & $33 \times 10^{-3}$ & $16 \times 10^{-3}$ & $17 \times 10^{-2}$ & $24 \times 10^{-2}$ & $16 \times 10^{-3}$ \\
\hline & & T.C.C. & N.D & N.D & $4 \times 10$ & N.D & $10 \times 10^{-2}$ \\
\hline & & F.C.C. & N.D & N.D & N.D & N.D & $2 \times 10^{-2}$ \\
\hline & & Mold & $5 \times 10^{-1}$ & $3 \times 10^{-2}$ & $2 \times 10^{-3}$ & $2 \times 10^{-2}$ & $1 \times 10^{-1}$ \\
\hline \multirow{12}{*}{ Yellow carrot } & \multirow{4}{*}{ Leaves } & T.A.C. & $12 \times 10^{-2}$ & $90 \times 10^{-3}$ & $35 \times 10^{-3}$ & $1 \times 10^{-1}$ & $5 \times 10^{-2}$ \\
\hline & & T.C.C. & $32 \times 10^{-3}$ & $25 \times 10^{-3}$ & $4 \times 10^{-3}$ & N.D & N.D \\
\hline & & F.C.C. & $5 \times 10^{-3}$ & N.D & N.D & N.D & N.D \\
\hline & & Mold & $25 \times 10^{-3}$ & $1 \times 10^{-2}$ & $1 \times 10^{-3}$ & $6 \times 10^{-2}$ & $1 \times 10^{-3}$ \\
\hline & \multirow{4}{*}{ Root } & T.A.C. & $7 \times 10^{-2}$ & $35 \times 10^{-1}$ & $4 \times 10^{-3}$ & $25 \times 10^{-2}$ & $26 \times 10^{-2}$ \\
\hline & & T.C.C. & N.D & N.D & $5 \times 10^{-1}$ & N.D & N.D \\
\hline & & F.C.C. & N.D & N.D & N.D & N.D & N.D \\
\hline & & Mold & $6 \times 10^{-2}$ & $2 \times 10^{-2}$ & $1 \times 10^{-2}$ & $2 \times 10^{-1}$ & $2 \times 10^{-1}$ \\
\hline & \multirow{4}{*}{ Seed } & T.A.C. & $80 \times 10^{-1}$ & $90 \times 10^{-3}$ & $43 \times 10^{-1}$ & $45 \times 10^{-1}$ & $15 \times 10^{-2}$ \\
\hline & & T.C.C. & $52 \times 10^{-1}$ & $75 \times 10^{-2}$ & $23 \times 10^{-1}$ & $3 \times 10^{-1}$ & N.D \\
\hline & & F.C.C. & $3 \times 10^{-1}$ & $70 \times 10^{-1}$ & $16 \times 10^{-1}$ & N.D & N.D \\
\hline & & Mold & $2 \times 10^{-3}$ & $1 \times 10^{-3}$ & $6 \times 10^{-3}$ & N.D & $2 \times 10^{-2}$ \\
\hline \multirow{4}{*}{\multicolumn{2}{|c|}{ Sodium propionate }} & T.A.C. & $37 \times 10^{-3}$ & $35 \times 10^{-2}$ & $30 \times 10^{-1}$ & $25 \times 10^{-1}$ & $9 \times 10^{-2}$ \\
\hline & & T.C.C. & N.D. & $7 \times 10^{-1}$ & $20 \times 10^{-1}$ & $7 \times 10^{-1}$ & N.D. \\
\hline & & F.C.C. & N.D. & N.D. & N.D. & N.D. & N.D. \\
\hline & & Mold & $5 \times 10^{-2}$ & $1 \times 10^{-3}$ & $2 \times 10^{-2}$ & $1 \times 10^{-1}$ & $1 \times 10^{-1}$ \\
\hline \multirow{4}{*}{\multicolumn{2}{|c|}{ Water }} & T.A.C. & $24 \times 10^{-3}$ & $38 \times 10^{-3}$ & $27 \times 10^{-3}$ & $60 \times 10^{-3}$ & $85 \times 10^{-3}$ \\
\hline & & T.C.C. & $17 \times 10^{-2}$ & $22 \times 10^{-2}$ & $18 \times 10^{-2}$ & $20 \times 10^{-3}$ & $25 \times 10^{-2}$ \\
\hline & & F.C.C. & $12 \times 10^{-2}$ & $9 \times 10^{-2}$ & $9 \times 10^{-2}$ & $15 \times 10^{-3}$ & $16 \times 10^{-2}$ \\
\hline & & Mold & $6 \times 10^{-1}$ & $8 \times 10^{-1}$ & $3 \times 10^{-2}$ & $1 \times 10^{-2}$ & $2 \times 10^{-1}$ \\
\hline
\end{tabular}

F.C.C $=$ fecal coliforms counts.

T.C.C $=$ total coliforms counts 
These compounds exhibited an inhibitory effect on several food- borne bacteria (Eklund, 1985) and (Moir and Eyles 1992).

(Kurosaki and Nishi ,1983), Showed that 6- methoxymellein had an inhibitory effect against a range of food- borne microorganisms.

The carrot extracts was more active against bacteria than against the yeast, and was more active against gram positive than against gram negative bacteria (Kabara, 1987).

Our results were in agreement with (Batt et al., 1980) who investigated that the chloroform extracted carrot roots was no inhibition of fungi. On contrary, Batt et al. 1980 did not observe any delay in fungi growth when various levels of chloroform extract from carrot root were added.

(Alderman and Morth,1976) reported that carrot extracted inhibited both fungi growth and aflatoxin production.

As shown in Table( 9) that the water extract of the seeds of the yellow carrot effective in reducing both the TAC, TCC, FCC in all wheat products during storage for 7 months. the treatment by alcohol extract of the seeds of the Yellow carrot as well as led to reduce the FCC in all wheat products to zero. in all products It is noted that most of the extracts had a strong impact on reducing the proportion of FCC except alcohol and aqueous extract of the roots of the yellow carrot.

Also notes that most of the extracts had a strong impact on reducing the proportion of TCC except chloroform extract of the red carrot leaves and aqueous extract of the yellow and red roots and sodium propionate.

While the rest of the extracts effects given appropriate and effective to cut all TAC, TCC, FCC through the period of storage for 7 months in most wheat products .

As shown in Table 10, the strongest effect on the fungi for treatment of water extract of to the seeds of Yellow carrot.

As shown in Table (10) free of all treated wheat products from mycotoxins during storage for 7 months. Despite the isolation of certain fungi producing the mycotoxins Such as a Aspergillus flavus. It is noted that Aspergillus is more presence of fungi during the storage period. Also, the chloroform extract of red and yellow carrot products was with a clear impact on the growth of fungi during storage period as well as sodium propionate. 
M.F. Emara et al.

9 
Table (10): Effect of water, ethanol, and chloroform extracted of red and yellow carrot (leaves, roots or seeds) on the fungal growth and its aflatoxin production in some wheat products after 7 months of storage.

\begin{tabular}{|c|c|c|c|c|c|c|c|c|c|}
\hline \multicolumn{2}{|c|}{ Treatments } & $\begin{array}{ll}\text { Type } & \text { of } \\
\text { extract } & \end{array}$ & Flour & $\begin{array}{l}\text { Brown } \\
\text { shorts }\end{array}$ & $\begin{array}{l}\text { White } \\
\text { shorts }\end{array}$ & $\begin{array}{l}\text { Fine } \\
\text { bran }\end{array}$ & $\begin{array}{l}\text { Coarse } \\
\text { bran }\end{array}$ & Isolated fungi & $\begin{array}{l}\text { Aflatoxin } \\
\text { content } \\
\mathrm{Mg} / \mathrm{Kg}\end{array}$ \\
\hline \multirow{6}{*}{$\begin{array}{l}\text { Red } \\
\text { carrot }\end{array}$} & \multirow{3}{*}{ leave } & $\begin{array}{l}\text { Water } \\
\text { extract }\end{array}$ & $11 \times 10^{-2}$ & $6 \times 10^{-1}$ & $8 \times 10^{-1}$ & $7 \times 10^{-3}$ & $10 \times 10^{-3}$ & \begin{tabular}{|l} 
Aspergillus \\
aculeatus\&Penicillium \\
digitatum
\end{tabular} & 0.0 \\
\hline & & \begin{tabular}{l|} 
Ethanol \\
extract
\end{tabular} & $9 \times 10^{-2}$ & $4 \times 10^{-1}$ & $6 \times 10^{-1}$ & $6 \times 10^{-3}$ & $8 \times 10^{-2}$ & Aspergillus niger & 0.0 \\
\hline & & \begin{tabular}{|l|} 
Chloroform \\
extract
\end{tabular} & $8 \times 10^{-3}$ & $5 \times 10^{-1}$ & $12 \times 10^{-2}$ & $1 \times 10^{-1}$ & $5 \times 10^{-2}$ & Aspergillus spp. & 0.0 \\
\hline & \multirow{3}{*}{ Root } & $\begin{array}{l}\text { Water } \\
\text { extract }\end{array}$ & $2 \times 10^{-1}$ & $2 \times 10^{-1}$ & $1 \times 10^{-1}$ & $1 \times 10^{-1}$ & $4 \times 10^{-1}$ & \begin{tabular}{|l} 
Aspergillus \\
aculeatus\&Penicillium \\
digitatum
\end{tabular} & 0.0 \\
\hline & & \begin{tabular}{|l|} 
Ethanol \\
extract
\end{tabular} & $4 \times 10^{-2}$ & $3 \times 10^{-2}$ & $6 \times 10^{-2}$ & $2 \times 10^{-2}$ & $3 \times 10^{-2}$ & $\begin{array}{|lr|}\text { Aspergillus niger } & \& \\
\text { Penicillium digitatum } & \\
\end{array}$ & 0.0 \\
\hline & & $\begin{array}{l}\text { Chloroform } \\
\text { extract }\end{array}$ & $3 \times 10^{-1}$ & $3 \times 10^{-2}$ & $6 \times 10^{-3}$ & $8 \times 10^{-2}$ & $5 \times 10^{-1}$ & \begin{tabular}{|l|l|} 
Aspergillus niger \\
\&Aspergillus versicolor
\end{tabular} & 0.0 \\
\hline \multirow{8}{*}{$\begin{array}{l}\text { Yellow } \\
\text { carrot }\end{array}$} & \multirow{3}{*}{ leave } & \begin{tabular}{|l|} 
Water \\
extract
\end{tabular} & $6 \times 10^{-1}$ & $7 \times 10^{-2}$ & $9 \times 10^{-2}$ & $3 \times 10^{-2}$ & $3 \times 10^{-2}$ & $\begin{array}{ll}\text { Aspergillus } & \text { sydowii } \\
\text { Alternaria SPP. } & \\
\end{array}$ & 0.0 \\
\hline & & $\begin{array}{l}\text { Ethanol } \\
\text { extract }\end{array}$ & $8 \times 10^{-2}$ & $14 \times 10^{-3}$ & $33 \times 10^{-3}$ & $7 \times 10$ & $6 \times 10^{-2}$ & $\begin{array}{|lr|}\text { Aspergillus } & \text { aculeatus \& } \\
\text { Aspergillus } & \text { flavus } \\
\text { Aspergillus } & \text { niger } \\
\text { \&Penicillium digitatum }\end{array}$ & 0.0 \\
\hline & & \begin{tabular}{|l|}
$\begin{array}{l}\text { Chloroform } \\
\text { extract }\end{array}$ \\
\end{tabular} & $12 \times 10^{-3}$ & $9 \times 10^{-2}$ & $13 \times 10^{-3}$ & $11 \times 10^{-2}$ & $5 \times 10^{-2}$ & $\begin{array}{l}\text { Aspergillus niger } \\
\text { \&Aspergillus versicolor }\end{array}$ & 0.0 \\
\hline & \multirow{3}{*}{ Root } & $\begin{array}{l}\text { Water } \\
\text { extract }\end{array}$ & $3 \times 10^{-1}$ & $2 \times 10^{-2}$ & $6 \times 10^{-2}$ & $4 \times 10^{-2}$ & $15 \times 10^{-3}$ & \begin{tabular}{|l|} 
Aspergillus \\
aculeatus\&Penicillium \\
digitatum
\end{tabular} & 0.0 \\
\hline & & \begin{tabular}{|l|} 
Ethanol \\
extract
\end{tabular} & $9 \times 10^{-2}$ & $7 \times 10^{-2}$ & $9 \times 10^{-2}$ & $18 \times 10^{-2}$ & $15 \times 10^{-2}$ & $\begin{array}{l}\text { Aspergillus niger } \\
\text { \&Aspergillus versicolor }\end{array}$ & 0.0 \\
\hline & & \begin{tabular}{|l|}
$\begin{array}{l}\text { Chloroform } \\
\text { extract }\end{array}$ \\
\end{tabular} & $5 \times 10^{-1}$ & $3 \times 10^{-1}$ & $3 \times 10^{-2}$ & $4 \times 10^{-2}$ & $13 \times 10^{-2}$ & $\begin{array}{l}\text { Aspergillus niger } \\
\text { \&Aspergillus versicolor }\end{array}$ & 0.0 \\
\hline & \multirow{2}{*}{ Seed } & $\begin{array}{l}\text { Ethanol } \\
\text { extract }\end{array}$ & $11 \times 10^{-3}$ & $4 \times 10^{-2}$ & $3 \times 10^{-2}$ & $3 \times 10^{-3}$ & $4 \times 10^{-3}$ & $\begin{array}{l}\text { Aspergillus niger } \\
\text { \&Aspergillus flavus } \\
\text { Fusarium verticillioides } \\
\end{array}$ & 0.0 \\
\hline & & $\begin{array}{l}\text { Chloroform } \\
\text { extract }\end{array}$ & $3 \times 10^{-2}$ & $2 \times 10^{-3}$ & $13 \times 10^{-3}$ & $3 \times 10^{-3}$ & $8 \times 10^{-3}$ & $\begin{array}{|lr|}\text { Aspergillus } & \text { flavus } \\
\text { \&Fusarium } & \text { verticillioides } \\
\text { \& Aspergillus spp. } & \\
\end{array}$ & 0.0 \\
\hline \multicolumn{3}{|c|}{ Sodium propounate } & $2 \times 10^{-1}$ & $5 \times 10^{-1}$ & $4 \times 10^{-2}$ & $5 \times 10^{-3}$ & $2 \times 10^{-1}$ & $\begin{array}{l}\text { Aspergillus niger } \\
\text { \&Aspergillus versicolor }\end{array}$ & 0.0 \\
\hline \multicolumn{3}{|l|}{ Water } & $7 \times 10^{-1}$ & $5 \times 10^{-2}$ & $7 \times 10^{-2}$ & $18 \times 10^{-1}$ & $13 \times 10^{-1}$ & \begin{tabular}{|lr} 
Aspergillus flavus \\
Aspergillus niger $\quad \&$ \\
Penicillium digitatum
\end{tabular} & 0.0 \\
\hline
\end{tabular}

\section{REFERENCES}

A.O.A.C.(1995): Official Methods of the Association of Official Analytical Chemists. $16^{\text {th }}$ ed., Arlington, Virginia, U.S.A.

A.O.A.C.(1998): Official Methods of the Association of Official Analytical Chemists. $17^{\text {th }}$ ed., Arlington, Virginia, U.S.A.,

A.P.H.A,1990 .American Puplic Health Association .Standard Methods for the examination of dairy products. $11^{\text {th }}$ ed.New York.

Abdalla, M. S. Atalla K.M and El-Sawi M.A. (2001). Effect of some plant waste extracts on growth and aflatoxin by Aspergillus flavus. Ann of Agric. Sci. Cairo Univ., 46 (2): 579-592. 


\section{M.F. Emara et al.}

Abdlahamid, A.M.; E.A. Sadik and E.A. Fayzalla (1995). Preserving power of some additives against fungal invasion and mycotoxin production in stored crushed corn containing different levels.

Alderman, G. G. and Marth, E. 1976. inhibition of growth and aflatoxin production of Aspergillus parasiticus by citrus oils. Z lebensm. Untersforsch 160: 353.

Applebaum, R.S. and Marth, E.H. (1982). Inactivation of aflatoxin: M1 in milk using hydrogen peroxide and hydrogen peroxide plus riboflavin or lactoperoxidse. J. of Food Protection, Vol. 45, No. 6 Pges 557-560 (April 1982).

Ashour, A.T. (1989): Studies on propolis gathering with special reference to its antimicrobial properties. M. Sc. Thesis, Dept. Economic Entomology. Fac. Agric.; Cairo Univ.

Babic I. C. Nguyen, M. J. Amiot and S. Aubert (1994). Antimicrobial activity of shredded carrot extracts on food- borne bacteria and yeast. Journal of Applied Baterilogy. 76, 135- 141.

Batt, C., Solberg, M., and ceponis., M. 1980 inhibition of aflatoxin production by carrot root extract. J. Food. Sci., 45: 1210.

Chen, L. and Y. Zhang (1987). Suppression for the in vitrolypho proliferative response to synergic L5178 $\mathrm{Y}$ tumor cells by fusarin C in mice. J. exp. Clin. Cancer Res. 6: 15-20.

Eklund, T. (1985) Inhibition of microbial growth at different pH levels by benzoic and propionic acids and esters of $p$ - hydroxybenzoic acid. International Journal of food Microbiology 2, 159- 167.

El-Kazzaz, M. K.; E. M. El- Assiuty; M. M. Badr, H. M. El-Zahby and M. I. Gouda (2003): Effect of some plant extracts and essential Oils in controlling sugar beet root rot disease caused by sclerotium rolfsii. Prod. The Tenth Cong. Phytopathology, 273-248. Dce. 9-10/2003, Giza, Egypt.

Faheid, Siham, M.M. and Hegazi, Nefisa, A.(1991). Effect of adding some legume flours on the nutritive value of cookies. Egypt. J. Food Sci., Vol. 19, No.1-2, pp.147-159.

Gelderblom, W.C.A.; K. Jaskiewiez; W.F.O Marasas; P.G. Thiel R.M. Horak; R. Velggar and N. P. J. Kirck (1998). Fumonisins mycotoxins with cancer- promoting activity produced byfusarium moniliform. Appl. Environ. Microbiol. 54: 1806- 1811.

Habegger, R., Schnitzler, W.H., 2000. Aroma compounds in the essential oil of carrot(Daucus carota L. ssp. sativus). 2. Intra-leaf distribution J. Appl. Bot. 74, 229-232.

Hansen, H.N.(1926).Simple of obtaining single spores culture. Science 64:387,1954.

Jacobs, D., Meyer, K., Kushi, L., and Folsom, A. 1998. Whole-grain intake may reduce the risk of ischemic heart disease death in postmenopausal women: the lowa women's health study. American Journal of Clinical Nutrition 68, 248.257.

Kabara, J. J. (1987) Fatty Acids and esters as antimicrobial / insecticidal agents. In Ecology and Metabolism of plant Lipids, American Chemial society Symposium Series No. 325. pp. 220- 238. 
Kainulainen, P., Nissinen, A., Piirainen, A., Tilikkala, K., Holopainen J.K., 2002. Essential oil composition in leaves of carrot varieties and preference of specialist and generalist sucking insect herbivores .Agric Forest Ent. 4, 211-216.

Kainulainen, P., Tarhanen, J., Tiilikkala, K., Holopainen, J.K., 1998. Foliarand emission composition of essential oil in two carrot varieties. J Agric. Food Chem. 46, 3780-3784.

Knight, J.B. and Kotschevar, L.H. (1979). Quantity food production planning and management. $\mathrm{ABCl}$ Book. Published by Van Nostrand Reinhold Company.

Kurosaki, F. and Nishi, A. (1983) Isolation and antimicrobial activity of the phytoalexin 6-methoxymellein from cultured carrot cells. Phytochemistry 22, 669- 672.

Legan, J. D. (1993). Mould spoilage of bread: the problem and some solutions. International Biodeterioration and Biodegradation,32.33-53.

Liu, S., Manson, J., Stampfer, M., Hu, F., Giovannucci, E., Colditz, G., Hennekens, C. and Willett, W. 2000. A prospective study of wholegrain intake and risk of type 2 diabetes mellitus in US women. American Journal of Public Health 90, 1409.1415.

Mitscher, L.A., Drake, S., Gollapudi, S.R. and Okwute, S.K. (1987) A modern look at folkloric use of anti-infective agents. Journal of Natural Products 50, 1025- 1040.

Moir ,C.J. and Eyles, M.J. (1992) Inhibition, injury, and inaetivation of four psychrotrophic foodborne bacteria by the preservatives methyl! $p$ hydroxybenzoate and potassium sorbate Journal of Food Protection 55, 360- 366.

Oxoid, Manual(2000).The Oxoid Manual of culture media ingredients and other laboratory services. $8^{\text {th }}$.Oxoid Ltd.

Riker,A.J.and Riker R.S.(1936).Introduction to research on plant disease.John,S.Swipt,Co.Inc.Sta.Lovis,Chicago,New York,117pp.

Pereira, M., Jacobs, D., Pins, J., Raatz, S., Gross M., Slavin, J., and Seaquist, E. 2002. Effect of whole grains on insulin sensitivity in overweight hyperinsulinemic adults. American Journal of Clinical Nutrition 75, 848.855.

Senalik, D., Simoin, P.W., 1987. Quantifying intra plant variation of volatile terpenes in carrot. Phytochemistry 26, 1975-1979.

Wiader, K. and Lamer E.; Zarawska (1996): Flavonoids of rare Artemisia Species and their antifungal properties.volatile terpenes in carrot. Phytochemistry 26, 1975-1979. 
M.F. Emara et al.

دراسـة إمكانيـة إلاستفادة مـن بعض المستخفلصـات الطبيعيـة كمضـادات للنمـوات الفطريـة لإطالة مدة حفظ القمح و منتجاته.

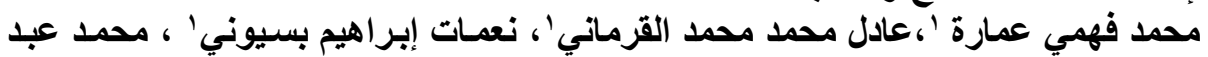

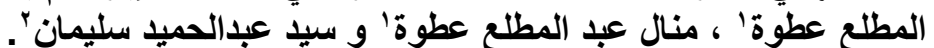

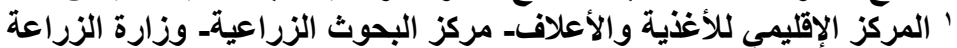

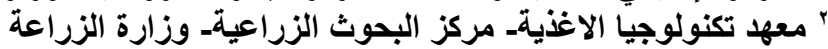

تم إستخلاص عروش وجذور وبذور الجزر الأصفر والأحمر بواسطة المـاء أو الإيثانول

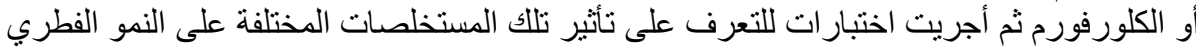

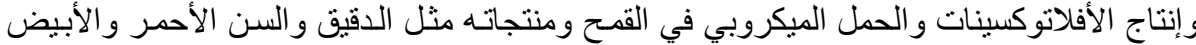

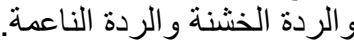

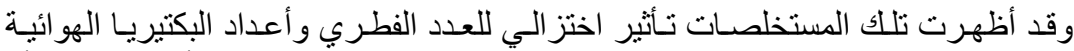

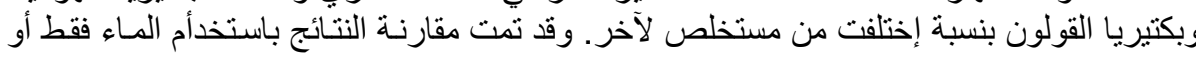

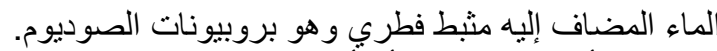

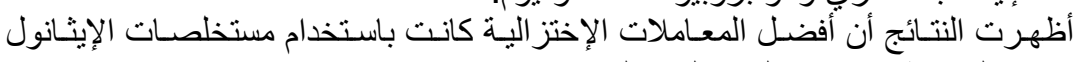
و الكلوروفوروم بالمقارنة باستخدام المستخلص الفئن المائي.

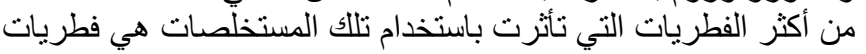

Penicillum funiculosum, Fusarium compactum, Fusarium chlomydosporum, Fusarium monilliforme, Fusarium rosum, Aspergillus fumagatus, Ochraceus sp., Aspergillus niger, Aspergillus flavus, Penicillium digitatum, Fusarium solani, and Fusarium pallidoroseum.

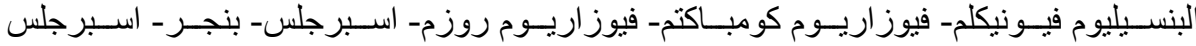

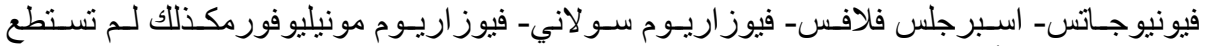
الفطريات إفراز أفلاتوكسينات في كل العينات المختبرة.

كلية الزراعة - جامعة المنصورة كلية الزراعة - جامعة القاهرة
قام بتحكيم البحث

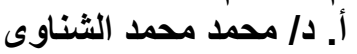

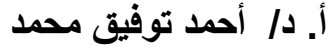


Table (9): Effect of water, ethanol, and chloroform extracted of red and yellow carrot (leaves, roots or seeds) on the microbial load in some wheat products after 7 months of storage.

\begin{tabular}{|c|c|c|c|c|c|c|c|c|c|c|c|c|c|c|c|c|c|}
\hline \multicolumn{2}{|c|}{ Treatments } & \multirow{2}{*}{ Type of extract } & \multicolumn{5}{|c|}{ T.A.C. } & \multicolumn{5}{|c|}{ T.C.C. } & \multicolumn{5}{|c|}{ F.C.C. } \\
\hline & & & Flour & shorts & shorts & bran & e bran & Flour & shorts & shorts & bran & e bran & Flour & shorts & shorts & bran & bran \\
\hline \multirow{6}{*}{$\begin{array}{l}\text { Red } \\
\text { carrot }\end{array}$} & \multirow[t]{3}{*}{ leave } & Water extract & $16 \times 10^{-2}$ & $55 \times 10^{-3}$ & $7 \times 10^{-2}$ & N.D & N.D & $8 \times 10^{-1}$ & $6 \times 10^{-1}$ & N.D. & N.D. & N.D. & N.D. & $15 \times 10^{-1}$ & N.D. & N.D. & N.D. \\
\hline & & Ethanol extract & $67 \times 10^{-1}$ & $4 \times 10^{-1}$ & $71 \times 10^{-1}$ & $5 \times 10$ & $33 \times 10^{-2}$ & N.D. & N.D & N.D. & N.D. & $2 \times 10^{2}$ & N.D. & N.D. & N.D. & N.D. & N.D. \\
\hline & & Chloroform extract & $10 \times 10$ & $40 \times 10^{-2}$ & $6 \times 10$ & $16 \times 10$ & $32 \times 10^{-1}$ & $4 \times 10$ & $32 \times 10^{-1}$ & $21 \times 10^{-1}$ & $11 \times 10^{-1}$ & $3 \times 10^{-3} 3$ & N.D. & N.D. & N.D. & N.D. & N.D. \\
\hline & \multirow[t]{3}{*}{ Root } & Water extract & $7 \times 10^{-1}$ & $8 \times 10^{2}$ & $26 \times 10^{-2}$ & $52 \times 10^{3}$ & $4 \times 10^{-2}$ & $38 \times 10^{-1}$ & $7 \times 10^{-2}$ & $30 \times 10^{-2}$ & $42 \times 10^{-1}$ & $35 \times 10^{-2}$ & $22 \times 10^{-1}$ & $12 \times 10^{-1}$ & $17 \times 10^{-1}$ & $12 \times 10^{-1}$ & $23 \times 10^{-1}$ \\
\hline & & Ethanol extract & $15 \times 10^{-2}$ & $7 \times 10^{-1}$ & $12 \times 10^{-3}$ & $11 \times 10^{3}$ & $16 \times 10^{-3}$ & $5 \times 10^{-1}$ & N.D. & N.D. & N.D. & N.D. & N.D. & N.D. & N.D. & N.D. & N.D. \\
\hline & & Chloroform extract & $33 \times 10^{-2}$ & $7 \times 10^{2}$ & $35 \times 10^{-3}$ & $4 \times 10^{-1}$ & $31 \times 10^{-3}$ & $9 \times 10^{2}$ & N.D. & N.D. & N.D. & $17 \times 10^{-2}$ & N.D. & N.D. & N.D. & N.D. & $7 \times 10^{-2}$ \\
\hline \multirow{8}{*}{$\begin{array}{l}\text { Yellow } \\
\text { carrot }\end{array}$} & \multirow[t]{3}{*}{ leave } & Water extract & $11 \times 10^{-1}$ & $40 \times 10^{-2}$ & $55 \times 10^{-3}$ & $18 \times 10^{2}$ & $15 \times 10^{-2}$ & $8 \times 10^{-1}$ & $3 \times 10^{-3}$ & $1 \times 10^{-3}$ & N.D. & $6 \times 10^{-1}$ & $1 \times 10^{-2}$ & $2 \times 10^{-3}$ & $4 \times 10^{3}$ & N.D. & N.D. \\
\hline & & Ethanol extract & $23 \times 10^{-2}$ & $21 \times 10^{-2}$ & $7 \times 10^{-2}$ & $2 \times 10^{-1}$ & $33 \times 10^{-2}$ & N.D. & N.D. & N.D. & N.D. & $21 \times 10^{-1}$ & N.D. & N.D. & N.D. & N.D. & N.D. \\
\hline & & Chloroform extract & $7 \times 10^{-2}$ & $25 \times 10^{-2}$ & $18 \times 10^{-2}$ & $3 \times 10^{-1}$ & $1 \times 10^{-1}$ & $14 \times 10^{-3}$ & $13 \times 10^{-2}$ & $45 \times 10^{-3}$ & N.D. & $3 \times 10^{3}$ & N.D. & $12 \times 10^{3}$ & N.D. & N.D. & N.D. \\
\hline & \multirow[t]{5}{*}{ Root } & Water extract & $16 \times 10^{-3}$ & $72 \times 10^{-3}$ & $21 \times 10^{-3}$ & $8 \times 10^{-1}$ & $11 \times 10^{-2}$ & $35 \times 10^{-2}$ & $33 \times 10^{-2}$ & $32 \times 10^{-2}$ & $5 \times 10^{-1}$ & $44 \times 10^{-3}$ & $21 \times 10^{-2}$ & $24 \times 10^{-2}$ & $21 \times 10^{-2}$ & $18 \times 10^{-2}$ & $2 \times 10^{-2}$ \\
\hline & & Ethanol extract & $6 \times 10^{-2}$ & $20 \times 10^{-1}$ & $3 \times 10^{-2}$ & $48 \times 10^{-2}$ & $42 \times 10^{-2}$ & $3 \times 10^{-2}$ & $4 \times 10^{-2}$ & N.D. & N.D. & N.D. & $7 \times 10^{-1}$ & $65 \times 10^{-1}$ & $21 \times 10^{-2}$ & $23 \times 10^{-2}$ & $18 \times 10^{-3}$ \\
\hline & & Chloroform extract & $9 \times 10^{-3}$ & $16 \times 10^{-2}$ & $65 \times 10^{-1}$ & $55 \times 10^{-2}$ & $52 \times 10^{-2}$ & $15 \times 10^{1}$ & N.D. & N.D. & N.D. & N.D. & N.D. & N.D. & N.D. & N.D. & N.D \\
\hline & & Ethanol extract & $17 \times 10^{-2}$ & $12 \times 10^{-2}$ & $3 \times 10^{-1}$ & $8 \times 10^{-3}$ & $19 \times 10^{-3}$ & $33 \times 10^{-1}$ & N.D. & $19 \times 10^{-1}$ & $9 \times 10^{-1}$ & N.D. & N.D. & N.D. & N.D. & N.D. & N.D. \\
\hline & & Chloroform extract & $83 \times 10^{-1}$ & $15 \times 10$ & $17 \times 10^{-2}$ & $60 \times 10^{-1}$ & $33 \times 10^{-2}$ & $53 \times 10^{-1}$ & $62 \times 10^{-1}$ & $17 \times 10^{-1}$ & $7 \times 10^{-1}$ & N.D. & $24 \times 10^{-1}$ & $5 \times 10^{-1}$ & $88 \times 10^{-1}$ & N.D. & N.D. \\
\hline \multicolumn{3}{|c|}{ Sodium propionate } & $54 \times 10^{-1}$ & $71 \times 10^{-3}$ & $63 \times 10^{-2}$ & $44 \times 10^{-1}$ & $17 \times 10^{-2}$ & $35 \times 10^{-1}$ & $23 \times 10^{-2}$ & $15 \times 10^{-1}$ & $18 \times 10^{-1}$ & $3 \times 10^{-4}$ & N.D. & $28 \times 10^{-4}$ & N.D. & N.D. & N.D. \\
\hline \multicolumn{3}{|l|}{ Nater } & $35 \times 10^{-3}$ & $54 \times 10^{-3}$ & $77 \times 10^{-3}$ & $12 \times 10^{-2}$ & $17 \times 10^{-2}$ & $23 \times 10^{-2}$ & $25 \times 10^{-2}$ & $38 \times 10^{-2}$ & $5 \times 10^{-2}$ & $5 \times 10^{-1}$ & $28 \times 10^{-2}$ & $2 \times 10^{-1}$ & $19 \times 10^{-2}$ & $34 \times 10^{-3}$ & $36 \times 10^{-2}$ \\
\hline
\end{tabular}

A.T.C = total aerobic counts.

T.C.C= total coliforms counts.

F.C.C $=$ fecal coliforms counts. 